\title{
ASSESSMENT OF THE CONTENT OF SELECTED TRACE ELEMENTS IN COCKSFOOT AND MAIZE MANURED WITH SEWAGE SLUDGE MIXED WITH HARD COAL ASH
}

\author{
GODLEWSKA, A. \\ Faculty of Natural Science, Siedlce University of Natural Sciences and Humanities \\ B. Prusa St. 12, 08-110 Siedlce, Poland \\ e-mail: agnieszka.godlewska@uph.edu.pl \\ (Received $18^{\text {th }}$ Dec 2017; accepted $19^{\text {th }}$ Mar 2018)
}

\begin{abstract}
The objective of the study was to determine changes in the content of selected trace elements in the biomass of test plants as affected by manuring with fresh and composted sewage sludge, hard coal ash, sewage sludge mixed with coal ash and liming at the background of mineral fertilisation. The experimental design was a completely randomised arrangement with three replicates. The following factors were examined: fertilisation with organic and mineral materials (fresh sewage sludge; composted sewage sludge; hard coal ash; calcium carbonate) and mineral fertilisation (no fertilisation; NPK fertilisation). An application of sewage sludge, hard coal ash, and sludge-ash mixtures significantly enhanced lithium content in the biomass of the 1st cut of cocksfoot, and molybdenum content in the 2nd cut grass. Hard coal ash mixed with sewage sludge contributed to an increase in lithium contents in the cocksfoot biomass of the 1st cut, titanium content in the 2nd cut of grass. Soil liming significantly increased lithium content in the plant biomass of 1st and 2nd cuts, as well as molybdenum contents in maize biomass. NPK nutrition significantly increased lithium, and titanium concentrations in the biomass of test plants.
\end{abstract}

Keywords: organic fertilisation, mineral fertilization, liming, heavy metal

\section{Introduction}

In recent years, a decline in the amount of organic manures applied to crops has been observed, which can frequently result in a negative soil balance of micro-elements. The phenomenon may disturb the appropriate content of micro-elements in crop plants which, in turn, is a very important qualitative characteristic taken into account while evaluating consumption- (Wojciechowska-Solis and Soroka, 2017) and feedstuff-related characteristics of the crops. Molybdenum and titanium are the elements which are indispensable for plant growth and development because they take part in metabolic processes. Additionally, molybdenum is a component of enzymes participating in transformations of nitrogen, phosphorus and sulphur compounds (Williams and Frausto, 2002; Bambara and Ndakidemi, 2010). The elements are also necessary for an appropriate development of animals and man (Kabata-Pendias and Mukherjee, 2007; Han et al., 2016).

Natural products for crop nourishment (Ciepiela and Godlewska, 2014; Ciepiela et al., 2016), industrial and municipal waste may be a valuable source of micro-elements and organic matter (Kalembasa and Godlewska, 2009a; Gondek, 2010; Kardos et al., 2011; Niewiadomska et al., 2015). Sewage sludge is of particular interest as it can be used for manuring purposes. However, sewage sludge may contain not only valuable nutrients but also harmful and toxic compounds (Usman et al., 2012) which, in turn, can be harmful for the environment, particularly if soil is acidic (Delibacak et al., 2009). The influence of these undesirable compounds may be reduced by an addition of substances such as hard coal ash or calcium carbonate, which contributes to an increase 
in sewage sludge $\mathrm{pH}$ thus reducing the solubility and phytoavailability of the majority of metals (Maksimovic et al., 2008; Kalembasa et al., 2008). It would make it possible to achieve two important economic goals, that is remediation of ash landfills and sewage sludge management.

The objective of the study was to determine changes in the content of selected trace elements in the biomass of test plants as affected by manuring with fresh and composted sewage sludge, hard coal ash, sewage sludge mixed with coal ash and liming at the background of mineral fertilisation.

\section{Materials and methods}

A pot experiment was established in a glasshouse located at the experimental unit of Siedlce University of Natural Sciences and Humanities in Poland $\left(52.169^{\circ} \mathrm{N}, 22.280^{\circ}\right.$ E). The experimental design was a completely randomised arrangement with three repetitions. The following factors were examined:

I - nutrition with organic and mineral materials (sewage sludge - raw and composted during three months) obtained from the sewage treatment plant in Siedlce - municipal and industrial sewage; hard coal ash from Energy Works in Siedlce; calcium carbonate). Sewage sludge was applied once, adding 5\% relative to soil weight. Sewage sludge and coal ash were mixed at the ratio of 2:1 (DM).

II - mineral nutrition (with or without NPK fertilization) Mineral fertilisers: urea, triple superphosphate and potassium sulphate, were applied pre-plant.

The soil used in the experiment was very loamy sand obtained from the $0-20 \mathrm{~cm}$ layer of grey brown podzolic soil. Before the experiment was set up, soil contents of nitrogen, carbon, available phosphorus and potassium were determined (respectively: $1.10,8.20,0.052$ and $0.071 \mathrm{~g} \mathrm{~kg}^{-1}$ ). Pots were filled with the soil at the amounts of $10 \mathrm{~kg}$ and humidity was maintained at the level of $60 \%$ of the full water capacity during the vegetation period.

Cocksfoot (Dactylis glomerata) was the test plant in the first study year; it was sown at the amount of $1.0 \mathrm{~g} \mathrm{pot}^{-1}$, and three cuts per growing season were harvested. In the second study year, maize (Zea mays) was grown at the density of 3 plants per pot, and harvested at the flowering stage to determine the relationship between mineralization rate of the organic materials tested in the study and plant uptake of nutrients. In the dried and powdered plant biomass, the total quantities of $\mathrm{Mo}, \mathrm{Ti}$, and $\mathrm{Li}$ were determined by means of the ICP-AES technique (Boss and Fredeen, 2004) after 'dry' mineralisation. Plant material (1 g) was digested in a muffle furnace at $450{ }^{\circ} \mathrm{C}$ with gradually increased temperature; then digested samples were dissolved in water solution of hydrochloric acid $\left(\mathrm{HCl}: \mathrm{H}_{2} \mathrm{O}, 1: 1\right)$ and evaporated until dry to decompose carbonates and separate silicates. The ash obtained was transferred to measure flasks containing $10 \% \mathrm{HCl}$ solution through a hard filter paper. Total molybdenum, titanium and lithium contents in sewage sludge and hard coal ash were also determined by the ICP-AES method following 'dry' mineralisation.

The program STATISTICA (data analysis software system), version 12 (www.statsoft.com) was used to statistically analyse the results. Significance of differences between means for the experimental factors was checked using Tukey's test at the significance level of $\alpha \leq 0.05$. 


\section{Results and discussion}

Hard coal ash and sewage sludge are composite materials whose chemical content and properties depend on many factors (Kalembasa et al., 2008). Sewage sludge applied in the experiment (Table 1) contained several times smaller amount of $\mathrm{Li}$ and $\mathrm{Ti}$ as hard coal ash. Molybdenum content in the sewage sludge and hard coal ash was similar and amounted to 5.67 and $3.76 \mathrm{mg} \mathrm{kg}^{-1}$, respectively.

Table 1. The content of Mo, Ti and Li in D.M. in sewage sludges and ash hard coal

\begin{tabular}{c|c|c}
\hline Element & Sewage sludge $\left(\mathbf{m g ~ k g}^{-\mathbf{1}}\right)$ & Ash hard coal $\left(\mathbf{m g ~ k g}^{\mathbf{- 1}}\right)$ \\
\hline $\mathrm{Mo}$ & 3.76 & 5.67 \\
\hline $\mathrm{Li}$ & 43.6 & 53.0 \\
\hline $\mathrm{Ti}$ & 92.6 & 617 \\
\hline
\end{tabular}

The cocksfoot grown in the experiment contained $2.74 \mathrm{mg}$ molybdenum $\mathrm{kg}^{-1} \mathrm{DM}$, on average, the amount varying in particular cuts and depending on the experimental factors (Table 2). In the first study year, molybdenum content increased in subsequent grass cuts in plots with no NPK nutrition, but the opposite tendency was observed in NPK-fertilised units. It may indicate that the process of organic compound mineralisation accelerated due to additional mineral nutrition. An application of fresh sewage sludge significantly increased molybdenum quantity in the biomass of the 2nd cocksfoot cuts, whereas composted sludge and hard coal ash contributed to a decline in molybdenum content in the 1st-cut plants compared with the control. Also McBride (2005) reported increased Mo contents after sludge application.

By contrast, according to Wichard (Wichard et al., 2009) molybdenum in soils can bind to organic matter, which can cause limiting its availability to plants.

Table 2. The content of Mo (in $\mathrm{mg} \mathrm{kg}^{-1} \mathrm{DM}$ ) in cocksfoot

\begin{tabular}{|c|c|c|c|c|c|c|c|c|c|c|c|c|}
\hline \multirow{4}{*}{$\begin{array}{c}\text { Organic } \\
\text { and } \\
\text { mineral } \\
\text { materials }\end{array}$} & \multicolumn{8}{|c|}{ NPK fertilisation } & \multirow{3}{*}{\multicolumn{3}{|c|}{ Means }} & \multirow{4}{*}{ Means } \\
\hline & \multicolumn{4}{|c|}{$\mathbf{0}$} & \multicolumn{4}{|c|}{ NPK } & & & & \\
\hline & \multicolumn{3}{|c|}{ Cuts } & \multirow{2}{*}{ Means } & \multicolumn{3}{|c|}{ Cuts } & \multirow{2}{*}{ Means } & & & & \\
\hline & $\mathbf{I}$ & II & III & & $\mathbf{I}$ & II & III & & $\mathbf{I}$ & II & III & \\
\hline 1 & $1.97 \mathrm{~cd}$ & 2.33 & $4.06 \mathrm{a}$ & 2.79 & $3.51 \mathrm{abc}$ & 2.67 & $1.14 \mathrm{~d}$ & 2.44 & $2.74 \mathrm{c}$ & $2.50 \mathrm{~cd}$ & $2.60 b c$ & $2.61 \mathrm{ab}$ \\
\hline 2 & $2.70 \mathrm{bc}$ & 3.84 & $3.42 \mathrm{abc}$ & 3.32 & $3.43 \mathrm{bc}$ & 3.36 & $1.52 \mathrm{~cd}$ & 2.77 & $3.07 \mathrm{bc}$ & $3.60 \mathrm{ab}$ & $2.47 \mathrm{bc}$ & $3.05 \mathrm{ab}$ \\
\hline 3 & $0.85 \mathrm{e}$ & 2.06 & $2.24 \mathrm{bc}$ & 1.72 & $2.26 \mathrm{~d}$ & 1.82 & $2.12 \mathrm{bcd}$ & 2.07 & $1.56 \mathrm{~d}$ & $1.94 \mathrm{~d}$ & $2.18 \mathrm{c}$ & $1.89 \mathrm{~b}$ \\
\hline 4 & $1.66 \mathrm{de}$ & 2.29 & $2.55 b c$ & 2.17 & $2.54 \mathrm{~cd}$ & 1.76 & $1.41 \mathrm{~cd}$ & 1.9 & $2.10 \mathrm{~d}$ & $2.03 \mathrm{~cd}$ & $1.98 \mathrm{c}$ & $2.04 \mathrm{~b}$ \\
\hline 5 & $1.20 \mathrm{de}$ & 1.83 & $2.07 \mathrm{c}$ & 1.7 & $3.62 \mathrm{ab}$ & 1.93 & $1.50 \mathrm{~cd}$ & 2.35 & $2.41 \mathrm{c}$ & $1.88 \mathrm{~d}$ & $1.79 \mathrm{c}$ & $2.03 \mathrm{~b}$ \\
\hline 6 & $2.32 b c$ & 3.56 & $3.56 \mathrm{ab}$ & 3.15 & $3.88 \mathrm{ab}$ & 2.05 & $3.07 \mathrm{ab}$ & 3 & $3.10 \mathrm{~b}$ & $2.81 b c$ & $3.32 \mathrm{ab}$ & $3.07 \mathrm{ab}$ \\
\hline 7 & $1.91 \mathrm{~cd}$ & 3 & $4.07 \mathrm{a}$ & 2.99 & $3.59 \mathrm{ab}$ & 2.75 & $2.86 \mathrm{abc}$ & 3.07 & $2.75 \mathrm{c}$ & $2.88 \mathrm{abc}$ & $3.47 \mathrm{ab}$ & $3.03 \mathrm{ab}$ \\
\hline 8 & $3.42 \mathrm{ab}$ & 3.39 & $3.63 \mathrm{ab}$ & 3.48 & $3.57 \mathrm{ab}$ & 2.64 & $1.43 \mathrm{~cd}$ & 2.55 & $3.50 \mathrm{ab}$ & $3.02 \mathrm{abc}$ & $2.53 b c$ & $3.01 \mathrm{ab}$ \\
\hline 9 & $3.82 \mathrm{a}$ & 4.73 & $3.75 \mathrm{a}$ & 4.1 & $4.45 \mathrm{a}$ & 2.83 & $3.84 \mathrm{a}$ & 3.71 & $4.14 \mathrm{a}$ & $3.78 \mathrm{a}$ & $3.80 \mathrm{a}$ & $3.90 \mathrm{ab}$ \\
\hline Means & $2.21 *$ & $3.00 *$ & $3.26 *$ & 2.82 & $3.42 *$ & $2.42 *$ & $2.10 *$ & 2.65 & 2.82 & 2.71 & 2.68 & 2.74 \\
\hline
\end{tabular}

1 - control object, 2 - sewage sludge, 3 - fermented sewage sludge, 4 - ash hard coal, 5 - sewage sludge + ash, 6 - ferment. sewage sludge + ash, 7 -liming, 8 - liming + sewage sludge + ash, 9 - liming + ferment. sewage sludge + ash

Values in columns for individual factors indicated with different small letters, differ significantly.

Asterisks within the same line indicate significant differences $(\alpha \leq 0.05)$. 
Ash mixed with composted sludge significantly increased molybdenum content in cocksfoot but its mixture with fresh sewage sludge contributed to a decline in molybdenum concentration in test plants. Liming of the soil to which sludge-ash mixtures were incorporated, significantly enhanced the molybdenum uptake by cocksfoot. Mineral nutrition of the 1st cut plants significantly increased molybdenum content in cocksfoot whereas in the 2nd and 3rd cuts a decline was observed.

Average molybdenum concentration in the biomass of maize grown in the second study year was $0.786 \mathrm{mg} \mathrm{kg}^{-1} \mathrm{DM}$ (Table 3), on average, and significantly depended on the waste materials applied. An application of sewage sludge, ash, and a sludge-ash mixture - both fresh and composted - significantly increased molybdenum content in maize compared with control plants. Soil liming increased the amount of the element in maize biomass as compared to control plants. Also, liming significantly enhanced molybdenum uptake by maize in plots where fresh and composted sludge-ash mixtures had been applied. Kalembasa and Godlewska (2009b) found that soil liming increased Mo content in plants, which was also confirmed in the present study.

Table 3. The content of Mo (in $\mathrm{mg} \mathrm{kg}^{-1} \mathrm{DM}$ ) in maize

\begin{tabular}{c|c|c|c}
\hline $\begin{array}{l}\text { Organic NPK fertilization } \\
\text { and mineral materials }\end{array}$ & $\mathbf{0}$ & NPK & Means \\
\hline 1 & 0.294 & 0.138 & $0.216 \mathrm{~b}$ \\
2 & 0.636 & 1.01 & $0.823 \mathrm{ab}$ \\
3 & 0.517 & 0.896 & $0.707 \mathrm{ab}$ \\
4 & 0.71 & 0.34 & $0.525 \mathrm{~b}$ \\
5 & 0.794 & 0.852 & $0.823 \mathrm{ab}$ \\
6 & 0.54 & 1.1 & $0.820 \mathrm{ab}$ \\
7 & 0.994 & 0.696 & $0.845 \mathrm{ab}$ \\
8 & 1.25 & 0.827 & $1.04 \mathrm{a}$ \\
9 & 1.41 & 1.14 & $1.28 \mathrm{a}$ \\
\hline Means & 0.794 & 0.778 & 0.786 \\
\hline
\end{tabular}

For explanations see Table 2.

Titanium content in cocksfoot biomass (Table 4) was $2.88 \mathrm{mg} \mathrm{kg}^{-1} \mathrm{DM}$, on average, and increased in subsequent cuts. The waste materials applied significantly reduced the titanium concentration in the 1st cut grass as compared to control plants. An addition of ash to fresh and composted sewage sludge resulted in a significant decline in titanium content in the biomass of the 1st cut cocksfoot. However, ash added to sludge increased titanium quantity in the 2 nd cut of test grass. NPK nutrition had a significant effect only for the 1st cut grass whose titanium content was significantly higher.

The average titanium content in maize (Table 5) was $2.40 \mathrm{mg} \mathrm{kg}^{-1} \mathrm{DM}$. Liming significantly increased titanium content in plants fertilised with fresh sewage sludge mixed with hard coal ash. Titanium concentration in maize grown in plots treated with composted sludge, ash, and fresh sludge mixed with ash was lower as compared to control plants. Also Kalembasa and Wysokiński (2009) reported higher titanium amounts in control maize compared with sewage sludge-treated plants. NPK nutrition significantly increased titanium concentration in the test plants. 
Table 4. The content of Ti (in $\mathrm{mg} \mathrm{kg}^{-1} \mathrm{DM}$ ) in cocksfoot

\begin{tabular}{|c|c|c|c|c|c|c|c|c|c|c|c|c|}
\hline \multirow{4}{*}{$\begin{array}{c}\text { Organic } \\
\text { and } \\
\text { mineral } \\
\text { materials }\end{array}$} & \multicolumn{8}{|c|}{ NPK fertilisation } & \multirow{3}{*}{\multicolumn{3}{|c|}{ Means }} & \multirow{4}{*}{ Means } \\
\hline & \multicolumn{4}{|c|}{$\mathbf{0}$} & \multicolumn{4}{|c|}{ NPK } & & & & \\
\hline & \multicolumn{3}{|c|}{ Cuts } & \multirow{2}{*}{ Means } & \multicolumn{3}{|c|}{ Cuts } & \multirow{2}{*}{ Means } & & & & \\
\hline & I & II & III & & I & II & III & & I & II & III & \\
\hline 1 & $1.58 \mathrm{~b}$ & 2.04 & $4.13 \mathrm{a}$ & 2.58 & $3.72 \mathrm{a}$ & 3.34 & $3.11 \mathrm{a}$ & 3.39 & $2.65 a$ & $2.69 \mathrm{abc}$ & 3.62 & 2.99 \\
\hline 2 & $1.56 \mathrm{~b}$ & 2.09 & $4.03 \mathrm{a}$ & 2.56 & $2.79 b$ & 2.85 & $3.23 \mathrm{a}$ & 2.96 & $2.18 b$ & $2.47 \mathrm{bc}$ & 3.63 & 2.76 \\
\hline 3 & $1.70 \mathrm{ab}$ & 2.32 & $3.18 \mathrm{~b}$ & 2.4 & $1.92 \mathrm{de}$ & 4.1 & $4.24 \mathrm{a}$ & 3.42 & $1.81 \mathrm{bc}$ & $3.21 \mathrm{abc}$ & 3.71 & 2.91 \\
\hline 4 & $1.58 \mathrm{~b}$ & 3.65 & $3.45 \mathrm{ab}$ & 2.89 & $2.60 \mathrm{bc}$ & 3.91 & $3.25 \mathrm{a}$ & 3.25 & $2.09 \mathrm{bc}$ & $3.78 \mathrm{ab}$ & 3.35 & 3.07 \\
\hline 5 & $0.96 \mathrm{c}$ & 3.96 & $4.72 \mathrm{a}$ & 3.21 & $1.40 \mathrm{ef}$ & 4.07 & $3.31 \mathrm{a}$ & 2.93 & $1.18 \mathrm{~d}$ & $4.02 \mathrm{a}$ & 4.02 & 3.07 \\
\hline 6 & $1.18 b c$ & 3.87 & $3.88 \mathrm{ab}$ & 2.98 & $0.87 f$ & 4.1 & $3.52 \mathrm{a}$ & 2.83 & $1.03 \mathrm{~d}$ & $3.99 \mathrm{a}$ & 3.7 & 2.9 \\
\hline 7 & $1.22 \mathrm{bc}$ & 2.54 & $3.05 \mathrm{~b}$ & 2.27 & $2.01 \mathrm{~cd}$ & 1.91 & $3.53 \mathrm{a}$ & 2.48 & $1.62 \mathrm{c}$ & $2.23 \mathrm{c}$ & 3.29 & 2.78 \\
\hline 8 & $2.30 \mathrm{a}$ & 3.94 & $3.79 \mathrm{ab}$ & 3.34 & $1.12 \mathrm{f}$ & 3.59 & $3.95 \mathrm{a}$ & 2.89 & $1.71 \mathrm{c}$ & $3.77 \mathrm{ab}$ & 3.87 & 3.12 \\
\hline 9 & $0.92 \mathrm{c}$ & 3.92 & $2.43 b$ & 2.42 & $1.33 \mathrm{f}$ & 3.81 & $3.89 \mathrm{a}$ & 3.01 & $1.13 \mathrm{~d}$ & $3.87 \mathrm{a}$ & 3.16 & 2.72 \\
\hline Means & $1.44^{*}$ & 3.15 & 3.63 & 2.72 & $1.97 *$ & 3.52 & 3.56 & 3.02 & 1.71 & 3.34 & 3.6 & 2.88 \\
\hline
\end{tabular}

For explanations see Table 2.

Table 5. The content of Ti (in $\mathrm{mg} \mathrm{kg}^{-1} \mathrm{DM}$ ) in maize

\begin{tabular}{c|c|c|c}
\hline $\begin{array}{l}\text { Organic NPK fertilization } \\
\text { and mineral materials }\end{array}$ & $\mathbf{0}$ & NPK & Means \\
\hline 1 & $2.12 \mathrm{ab}$ & $2.51 \mathrm{bc}$ & $2.32 \mathrm{ab}$ \\
2 & $2.22 \mathrm{ab}$ & $2.90 \mathrm{abc}$ & $2.56 \mathrm{ab}$ \\
3 & $1.76 \mathrm{~b}$ & $2.39 \mathrm{bc}$ & $2.08 \mathrm{~b}$ \\
4 & $2.02 \mathrm{ab}$ & $2.06 \mathrm{c}$ & $2.04 \mathrm{~b}$ \\
5 & $1.61 \mathrm{~b}$ & $2.50 \mathrm{bc}$ & $2.06 \mathrm{~b}$ \\
6 & $1.86 \mathrm{ab}$ & $3.45 \mathrm{a}$ & $2.66 \mathrm{ab}$ \\
7 & $2.38 \mathrm{ab}$ & $2.67 \mathrm{abc}$ & $2.53 \mathrm{ab}$ \\
8 & $2.44 \mathrm{ab}$ & $3.15 \mathrm{ab}$ & $2.80 \mathrm{a}$ \\
9 & $2.70 \mathrm{a}$ & $2.35 \mathrm{bc}$ & $2.53 \mathrm{ab}$ \\
\hline Means & $2.12 *$ & $2.66 *$ & 2.4 \\
\hline
\end{tabular}

For explanations see Table 2.

The average lithium content in cocksfoot biomass (Table 6) amounted to $23.4 \mathrm{mg} \mathrm{kg}^{-1}$ DM, and it was affected by the experimental factors. Waste materials contributed to significant differences between the cuts, but lithium content did not exceed $50 \mathrm{mg} \mathrm{kg}^{-1}$ DM, which is assumed as the limit for root crops. The content was lower in all the cuts of control cocksfoot biomass compared with the remaining units. Hard coal ash mixed with fresh and composted sewage sludge contributed to increased lithium contents in the cocksfoot biomass of each cut the differences being significant for the 1st cut only. Soil liming in plots where sludge-ash mixtures were used, enhanced the quantity of the element in all the cuts of the test plants. Moreover, there were recorded significantly higher lithium concentrations in 1st and 2nd cut plants harvested from limed plots, and a significantly higher mean concentration calculated across the three cuts for limed units 
compared with the control grass, which was not consistent with other authors' reports. According Aral and Vecchio-Sadus (2008) plant uptake of lithium is greater in acidic soils than in alkali soils. By contrast, Wysokiński and Kalembasa (2009) found a higher lithium content in sunflower grown in plots manured with fresh and composted sewage sludge mixed with brown coal and $\mathrm{CaO}$, compared with plants manured with sewage sludge only. Mineral nutrition increased the lithium content in the 1st and 2nd cuts but it insignificantly affected the lithium uptake by cocksfoot in the $3 \mathrm{rd}$ cut.

Lithium level in maize biomass (Table 7) was $14.5 \mathrm{mg} \mathrm{kg}^{-1} \mathrm{DM}$, on average. Although no significant differences were found, lithium content tended to increase in maize plants due to an application of waste materials and their mixtures compared with the control. Hard coal ash mixed with fresh and composted sewage sludge had no effect on the uptake of lithium by plants. Mineral nutrition was the only factor which contributed to a significant increase in the maize content of lithium.

Table 6. The content of Li (in $\mathrm{mg} \mathrm{kg}^{-1} \mathrm{DM}$ ) in cocksfoot

\begin{tabular}{|c|c|c|c|c|c|c|c|c|c|c|c|c|}
\hline \multirow{4}{*}{$\begin{array}{l}\text { Organic } \\
\text { and } \\
\text { mineral } \\
\text { materials }\end{array}$} & \multicolumn{8}{|c|}{ NPK fertilisation } & \multirow{3}{*}{\multicolumn{3}{|c|}{ Means }} & \multirow{4}{*}{ Means } \\
\hline & \multicolumn{4}{|c|}{$\mathbf{0}$} & \multicolumn{4}{|c|}{ NPK } & & & & \\
\hline & \multicolumn{3}{|c|}{ Cuts } & \multirow{2}{*}{ Means } & \multicolumn{3}{|c|}{ Cuts } & \multirow{2}{*}{ Means } & & & & \\
\hline & $\mathbf{I}$ & II & III & & $\mathbf{I}$ & II & III & & I & II & III & \\
\hline 1 & 18 & 12.1 & $11.4 \mathrm{e}$ & 13.8 & 17.7 & 23.4 & $28.1 \mathrm{~b}$ & 23.1 & $17.9 \mathrm{c}$ & $17.8 \mathrm{c}$ & $19.8 \mathrm{abc}$ & $18.5 b$ \\
\hline 2 & 26.7 & 19.4 & $26.6 \mathrm{a}$ & 24.2 & 28.6 & 19.4 & $21.7 \mathrm{~d}$ & 23.2 & $27.7 \mathrm{ab}$ & $19.4 \mathrm{abc}$ & 24.2abc & $23.7 \mathrm{ab}$ \\
\hline 3 & 27.2 & 24.2 & $25.4 \mathrm{a}$ & 25.6 & 26.7 & 25.6 & $28.1 \mathrm{bc}$ & 26.8 & $27.0 \mathrm{ab}$ & $24.9 \mathrm{abc}$ & $26.8 \mathrm{ab}$ & $26.2 \mathrm{a}$ \\
\hline 4 & 23.9 & 25.1 & $20.7 \mathrm{c}$ & 23.2 & 24.6 & 22.7 & $20.1 \mathrm{e}$ & 22.5 & $24.3 \mathrm{ab}$ & $23.9 \mathrm{abc}$ & 20.4abc & $22.9 \mathrm{ab}$ \\
\hline 5 & 27.3 & 14.3 & $24.1 \mathrm{~b}$ & 21.9 & 31.2 & 26.6 & $30.9 \mathrm{a}$ & 29.6 & $29.3 \mathrm{a}$ & $20.5 \mathrm{abc}$ & $27.5 \mathrm{a}$ & $25.7 \mathrm{ab}$ \\
\hline 6 & 25.7 & 21.7 & $24.2 b$ & 23.9 & 33.3 & 33.2 & $22.7 \mathrm{~cd}$ & 30 & $29.5 \mathrm{a}$ & $27.5 \mathrm{ab}$ & $23.5 \mathrm{abc}$ & $26.8 \mathrm{a}$ \\
\hline 7 & 27 & 25.2 & $20.6 c$ & 24.3 & 28.5 & 30.5 & $23.5 \mathrm{c}$ & 27.5 & $27.8 \mathrm{ab}$ & $27.9 \mathrm{a}$ & $22.1 \mathrm{abc}$ & $25.9 a$ \\
\hline 8 & 21.2 & 16.9 & $20.6 c$ & 19.6 & 24.3 & 24.7 & $17.3 \mathrm{f}$ & 22.1 & $22.8 b c$ & $20.8 \mathrm{abc}$ & $19.0 \mathrm{bc}$ & $20.8 \mathrm{ab}$ \\
\hline 9 & 21.1 & 16.8 & $17.8 \mathrm{~d}$ & 18.6 & 28 & 21.4 & $16.3 \mathrm{f}$ & 21.9 & $24.6 \mathrm{ab}$ & $19.1 b c$ & $17.1 \mathrm{c}$ & $20.2 \mathrm{ab}$ \\
\hline Means & $24.2 *$ & $19.5^{*}$ & 21.3 & $21.7 *$ & $27.0 *$ & $25.3^{*}$ & 23.2 & $25.2 *$ & 25.6 & 22.4 & 22.3 & 23.4 \\
\hline
\end{tabular}

For explanations see Table 2.

Table 7. The content of Li (in $\mathrm{mg} \mathrm{kg}^{-1} \mathrm{DM}$ ) in maize

\begin{tabular}{c|c|c|c}
\hline $\begin{array}{l}\text { Organic } \\
\text { and mineral materials }\end{array}$ & $\mathbf{0}$ & NPK & Means \\
\hline 1 & $16.6 \mathrm{a}$ & $9.83 \mathrm{c}$ & 13.2 \\
2 & $14.7 \mathrm{a}$ & $13.5 \mathrm{abc}$ & 14.1 \\
3 & $16.3 \mathrm{a}$ & $10.6 \mathrm{bc}$ & 13.5 \\
4 & $13.9 \mathrm{a}$ & $17.4 \mathrm{ab}$ & 15.7 \\
5 & $18.1 \mathrm{a}$ & $11.5 \mathrm{bc}$ & 14.8 \\
6 & $16.4 \mathrm{a}$ & $14.7 \mathrm{abc}$ & 15.6 \\
7 & $17.9 \mathrm{a}$ & $9.12 \mathrm{c}$ & 13.5 \\
8 & $11.7 \mathrm{a}$ & $15.7 \mathrm{abc}$ & 13.7 \\
9 & $13.5 \mathrm{a}$ & $18.8 \mathrm{a}$ & 16.2 \\
\hline Means & $15.5^{*}$ & $13.5^{*}$ & 14.5 \\
\hline
\end{tabular}

For explanations see Table 2. 


\section{Conclusions}

An application of sewage sludge, hard coal ash, and sludge-ash mixtures significantly enhanced lithium content in the biomass of the 1st cut of cocksfoot, molybdenum content in the 2nd cut grass. Hard coal ash mixed with sewage sludge contributed to an increase in lithium contents in the cocksfoot biomass of the 1st cut, titanium content in the 2 nd cut of grass. Soil liming significantly increased lithium content in the plant biomass of 1 st and 2nd cuts, as well as molybdenum contents in maize biomass. NPK nutrition significantly increased lithium, titanium and barium concentrations in the biomass of test plants.

In summary, it should be noted that the degree of organic matter decomposition and origin has a considerable effect on the characteristics discussed in the work. Further studies are needed to develop more comprehensive results and evaluate the impact of different rates of organic and mineral materials.

\section{REFERENCES}

[1] Aral, H., Vecchio-Sadus, A. (2008): Toxicity of lithium to humans and the environmental - a literature review. - Ecotoxicology and Environmental Safety 70: 349-356.

[2] Bambara, S., Ndakidemi, P. A. (2010): The potential roles of lime and molybdenum on the growth, nitrogen fixation and assimilation of metabolites in nodulated legume: A special reference to Phaseolus vulgaris L. - African Journal of Biotechnology 8(17): 2482-2489.

[3] Boss, C. B., Fredeen, K. J. (2004): Concepts, Instrumentation and Techniques in Inductively Coupled Plasma Optical Emission Spectrometry. - Perkin-Elmer, Shelton.

[4] Ciepiela, G. A., Godlewska, A. (2014): Changes in protein compounds and momosaccharidesin selected grass species following an application of seaweed extract. Polish Journal of Environmental Studies 23(1): 29-35.

[5] Ciepiela, G. A., Godlewska, A., Jankowska, J. (2016): The effect of seaweed Ecklonia maxima and mineral nitrogen on fodder grass chemical composition. - Environmental Science and Pollution Research 23: 2301-2307.

[6] Delibacak, S., Okur, B., Ongun, A. R. (2009): Influence of treated sewage sludge applications on temporal variations of plant nutrients and heavy metals in a Typic Xerofluvent soil. - Nutrient Cycling in Agroecosystems 83: 249-257.

[7] Gondek, K. (2010): Assessment of the influence of sewage sludge fertilization on yield and content of nitrogen and sulphur in maize (Zea may.). - Journal of Elementology 15(1): 65-79.

[8] Han, Y., Rui, M., Hao, Y., Rui, Y., Tang, X., Liu, L., Cao, W. (2016): Effects of organic fertilizer input on heavy metal content and speciation in vegetable and soil. - Fresenius Environmental Bulletin 25(2): 647-657.

[9] Kabata-Pendias, A., Mukherjee, A. B. (2007): Trace Elements from Soil to Human. Springer, Berlin.

[10] Kalembasa, S., Godlewska, A. (2009a): Influence of varied nutrition and liming on $\mathrm{Cu}$, $\mathrm{Zn}$, and Fe contents at test plants. - Fresenius Environmental Bulletin 18(7a): 1210-1213.

[11] Kalembasa, S., Godlewska, A. (2009b): The influence of sewage sludge, soil type and liming on the content of Mo, B and $\mathrm{Sr}$ in the biomass of annual ryegrass. - Advances of Agricultural Sciences Problem Issues 541: 171-179 (in Polish; abstract in English).

[12] Kalembasa, S., Wysokiński, A. (2009): The influence of mineral and organic additions to the waste activated sludges and the duration of composting process on the content of $\mathrm{Ti}$, Sr, Co and Li in plants. - Fresenius Environmental Bulletin 18(10a): 1927-1931. 
[13] Kalembasa, S., Godlewska, A., Wysokiński, A. (2008): The chemical composition of ashes from brown coal and hard coal in the content of their agricultural utilization. - Soil Science Annual 59(2): 93-97 (in Polish; abstract in English).

[14] Kardos, L., Juhasz, A., Palko, G. Y., Olah, J., Barkacs, K., Zaray, G. Y. (2011): Enzyme activity analyses of anaerobic fermented sewage sludges. - Applied Ecology and Environment Research 9(4): 333-339.

[15] Maksimovic, S., Blagojevic, S., Pilic, R. and Stanojkovic, A. (2008): Quality characteristics of some grass cultivated on fly-ash deposits of a thermal power station. Fresenius Environmental Bulletin 17(5): 584-588.

[16] McBride, M. B. (2005). Molybdenum and copper uptake by forage grasses and legumes grown on a metal-contaminated sludge site. - Communications in Soil Science and Plant Analysis 36(17-18): 2489-2501.

[17] Niewiadomska, A., Sulewska, H, Wolna-Maruwka, A., Szymańska, G. (2015): The effect of fertilisation of sewage sludge on soil activity in the year of application and in successive years following its introduction in maize grown for grain. - Fresenius Environtal Bulletin 24(5): 1707-1715.

[18] Usman, K., Khan, S, Ghulam, S., Khan, M. U., Khan, N., Khan, M. A., Khan Khalil, S. (2012): sewage sludge: An important biological Resource for sustainable agriculture and its environmental implications. - American Journal of Plant Sciences 3: 1708-1721.

[19] Wichard, T., Mishra, B., Myneni, S. C. B., Bellenger, J. B., Kraepiel, A. M. L. (2009): Storage and bioavailability of molybdenum in soils increased by organic matter complexation. - Nature Geoscience 2: 625-629.

[20] Williams, R. J. P., Frausto da Silva, J. J. R. (2002): The involvement of molybdenum in life. - Biochemical and Biophysikal Research Communications 292: 293-299.

[21] Wojciechowska-Solis, J., Soroka, A. (2017): Motives and barriers of organic food demand among Polish consumers: A profile of the purchasers. - British Food Journal 119(9): 2040-2048.

[22] Wysokiński, A., Kalembasa, S. (2009): The influence of alkalizing and composting process of sewage sludge on aluminium, lithium and manganese content in plants. Environmental Protection and Natural Resources 41: 505-515. 